\title{
Denationalisation, Assassination, Territory: Some (U.S.-Prompted) Reflections
}

\author{
Linda Bosniak
}

Unlike the several liberal states Macklin cites which have already, or will soon, deploy citizenship revocation as an anti-terrorism mechanism, the United States is unlikely to implement similar policies. The U.S. Constitution has been interpreted to prohibit unilateral citizenship-stripping as a tool of governance. Instead, denationalisation via expatriation in the U.S. requires the individual to specifically consent to relinquish the status, and such consent cannot be inferred from acts alone - even from acts which some (including some commentators in this symposium) would like to characterise as intrinsically antithetical to citizenship identity. The vigorous safeguarding of individual citizenship in US law is borne of the nation's history of racebased slavery and its aftermath. Today, courts quite stringently interpret the Fourteenth Amendment's guarantee of citizenship status for 'all persons born or naturalised in the U.S.' I realise the matter of slavery will seem remote from the concerns of contemporary transnational debates over citizenship-stripping in Europe and Canada (although it might be worth wondering, another day, if 'slavery' could ever serve - along with 'political death' - as a fruitful analytic metaphor here. Think, for example, of the recent mass denationalisation of Dominican-born Haitians in the Dominican Republic ${ }^{1}$ ). Nevertheless, we know that national citizenship law and policy look inward as well as outward. In the U.S., the legacy of slavery forms a part of a deep conversational grammar about citizenship in a way that will almost certainly stay the hand of congressional advocates of the 'Enemy Expatriation Act' and similar proposed measures.

That the US is not about to join Britain and Canada and other states in a politics of forcible expatriation, however, by no means implies that the US does not wish to 'permanently eliminate' suspected or confirmed terrorists, nor that it is unable to do so. Indeed, we have recently seen deployment by

\footnotetext{
1 'Stateless in the Dominican Republic: Residents stripped of citizenship', Aljazeera America, 4 May 2014, available at http://america.aljazeera.com/ articles/2014/5/4/stateless-in-thedominicanrepublicresidentsstrippedofcitizenship.html
} 
the U.S. of what Macklin calls 'the sovereign's other technique for permanent elimination' of such persons: namely: state-inflicted death. The 2013 assassination of U.S. citizen Anwar al-Awlaki in Yemen was a widely noted recent example of this policy (with the apparently accidental assassination Anwar's 16-year-old U.S. citizen son, Abdulrahman, a notorious followup.) For some commentators, state acts of this kind may appear more 'proportional' to the claimed offenses than expatriation is. Personally, I would not endorse any policy of assassination, much less when visited upon its target without application of due process. But my comments don't concern the policy's defensibility. Instead, I raise the al-Awlaki case to frame a few brief observations about the relationship between citizenship-stripping, targeted assassination and territoriality in the United States and beyond.

First, as Macklin points out, states strip citizenship not merely in order to territorially banish the affected going forward but sometimes perhaps, as a 'prelude to assassination,' whether by themselves or others. In particular, Macklin cites the cases of Britons who were denationalised and subsequently killed by US drone strike in Somalia. ${ }^{2}$ Denationalisation here can be understood to have strategically relieved Britain of the imperative of protecting its own nationals from harm, including assassination, by another state party. In this scenario, denationalisation is not merely a form of political death; as Macklin argues, it may facilitate bodily death as well.

Nevertheless, we have also seen that since United States law makes it 'easier to kill than expatriate,' in Peter Spiro's succinct phrasing, ${ }^{3}$ the U.S. government does not await denationalisation to assassinate its own citizens. We could, indeed, view assassination of al Awlaki senior as the nation's only route to denationalise him, with assassination serving as the actual mechanism for stripping his citizenship.

On the other hand, al Awlaki's assassination precipitated a fascinating debate in the United States about territoriality and citizenship which perhaps bears on our transnational conversation here. In the wake of the killing, a segment of the US political class erupted in concerted anxiety about whether

2 See 'British terror suspects quietly stripped of citizenship... then killed by drones,' The Independent, 28 February 2013, available at http://www.independent.co.uk/news/uk/crime/british-terror-suspects-quietly-stripped-of-citizenship-then-killed-by-drones-8513858.html and 'Britain Increasingly Invokes Power to Disown Its Citizens', The New York Times, 9 April 2014, available at http://www.nytimes.com/2014/04/10/world/europe/britains-power-to-disownits-citizens-raises-questions.html? $\mathrm{r}=3$

3 Spiro, P. (2014), 'Expatriating Terrorists', Fordham Law Review 82 (5):

2169-2187, at 2177. 
the government actually claimed authority not only to assassinate US citizens abroad but to do the same 'on US soil.' Senator Rand Paul led a filibuster against the confirmation of proposed CIA Director John Brennan, promising to 'speak as long as it takes until the alarm is sounded from coast to coast that our Constitution is important, that your rights to trial by jury are precious, [and] that no American should be killed by a drone on American soil without first being charged with a crime, [and] found...guilty by a court.' Much media fan-flaming followed, and eventually, Attorney General Eric Holder conceded that targeting any U.S. citizen for assassination within national territory - in the absence of imminent threat - is unacceptable. ${ }^{4}$

What was striking in this episode was the normative distinction taken up in popular discourse between in-country and out-of-country citizen assassination. The implied claim was that death of a citizen by its own government was somehow uniquely intolerable when accomplished inside national territorial bounds. For that moment, at least, the American political imaginary seemed to coalesce more around fear of tyrannical government than of the foreign terrorist within.

Of course, if government were in fact bound by this normative logic i.e., that territorially present citizens are uniquely out of bounds for targeted killing - then the target would need to be denationalised and/or territorially expelled first and only executed thereafter. Yet since the US state is constrained in denationalising citizens, and since, like all states, it is precluded from expelling citizens, it would seem to have to await such person's travel outside the country in order to strike. This seems odd, yet it notably parallels the form denationalisation practices take in many countries - where, according to Macklin, governments tend to strip citizenship from those citizens who are already located abroad. In both settings, we see not only that territorially-present citizens are regarded as possessing more fundamental protections against government power than those territorially absent, but that governments make opportunistic use of citizen absence to act against them. Among other things, this amounts to a kind of penalty on citizen mobility, and seems to rest on an arbitrary locational distinction. This, at least, is what the US Supreme Court itself concluded in 1957 in a related context when it wrote that a citizen's constitutional rights may not 'be stripped away just because he happens to be in another land. ${ }^{5}$

4 For more extensive discussion and citations, see Bosniak, L. (2013), 'Soil and Citizenship', Fordham L. Rev. 82 (5): 2069-2075.

5 Reid v. Covert, 354 U.S. 1 (1957). 
Of course, territoriality's relationship with citizenship sometimes reaches back well beyond any possible denationalisation and assassination to the moment of the citizen's birth. For some, the Awlaki affair itself evoked longstanding debates about assignment of citizenship based on territorial presence at birth, with Awlaki an exemplar of the 'nominal citizen' whose extraterritoriality for most of his post-natal life rendered his social attachment to the nation 'highly attenuated' (to use Macklin's phrase). Yet in this setting as well, the United States will remain robustly-citizenship protective. The country's inclusive birthright citizenship rules are another stanchion of its post-slavery, post-Civil War, constitutionalism. Consequently, and much as some 'anti-birthers' wish it were otherwise, citizenship cannot be easily eliminated on the front end here, except by way more stringent immigration and border control policies to prevent, ex ante, potential parents' territorial presence. Broadly drawn and often selectively-applied grounds of inadmissibility and deportability based on 'terrorist activity' arguably go some of the distance in accomplishing that end. ${ }^{6}$

In short, citizenship status, especially for those in national territory, still remains more secure in the U.S. than it is in some other national settings. Our government works to counter the alleged 'bad guys' (Bauböck's shorthand) by different means.

Open Access This chapter is licensed under the terms of the Creative Commons Attribution 4.0 International License (http://creativecommons.org/licenses/by/4.0/), which permits use, sharing, adaptation, distribution and reproduction in any medium or format, as long as you give appropriate credit to the original author(s) and the source, provide a link to the Creative Commons license and indicate if changes were made.

The images or other third party material in this chapter are included in the chapter's Creative Commons license, unless indicated otherwise in a credit line to the material. If material is not included in the chapter's Creative Commons license and your intended use is not permitted by statutory regulation or exceeds the permitted use, you will need to obtain permission directly from the copyright holder.

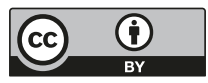

6 E.g., Legomsky, S. H. (2005), 'The Ethnic and Religious Profiling of Noncitizens: National Security and International Human Rights', Boston College Third World Law Journal 25 (1): 161-196. 